\title{
Commercial and Green Corrosion Inhibitors for Reinforced Concrete Structures: A Review
}

\author{
Mohammad Ali Asaad ${ }^{1}$, Mohammed Noori Hussein ${ }^{2}$, Ahmad Majied Alkadhimi ${ }^{3}$, Ali Taha Saleh ${ }^{4}$ \\ 1,2,3 Department of Civil Engineering, Iraq University College (IUC), Basra, Basra, Iraq \\ ${ }^{4}$ Department of Chemistry, College of Science, University of Misan, Misan, Iraq
}

\begin{abstract}
Civil construction projects have always met with corrosion issues affecting reinforcements, both in circumstances where the relevant standards were not observed during concrete design and preparation and in structures close to bridges, coasts, ports, quays and so on, where exposure to an aggressive environment can lead to damage such as rust spots, cracking and delamination of the concrete cover, which constitutes a hazard for the end-user. Inhibitors are frequently simple to apply and extensively utilised to reduce the corrosion rate of many steel structures in the aggressive environments without causing any significant disruption to the process. The article reviews information related to the mechanism of corrosion prevention methods to increase the service life of structures in coastal areas. This is included commercial inhibitors (inorganic and organic), sealers and barriers, eco-friendly inhibitor, and green inhibitor combined with nanoparticles. An analysis of the published literature demonstrates a general agreement that one of the most significant problems affecting reinforced concrete structures is corrosion of the steel reinforcements.
\end{abstract}

KEYWORDS: Corrosion, steel reinforcement, commercial inhibitors, green inhibitors, chloride attack.

\section{INTRODUCTION}

At the present time, reinforced concrete is the most commonly used construction material, its continuing success being primarily down to its low cost and desirable engineering properties in comparison to other building materials e.g. steel or timber [1]. These structures are essential to the standard of living of millions of people globally, while premature or sudden structural failure can be disastrous not only in terms of economy and loss of time, but occasionally also loss of life [2,3]. Degradation of these RC structures can arise due to physical factors (e.g. cracking due to repeated freeze-thaw cycles or thermal mismatch between cement and aggregates), mechanical factors (e.g. impacts, abrasion, erosion) or chemical factors (e.g. acid attack, alkali-aggregate reaction, leaching, seawater attack, sulphate attack and etc.) [4]. The two main mechanisms leading to corrosion of steel reinforcements in concrete are concrete carbonation and chloride attack. The latter, generally arising from the presence of chloride ions in seawater or de-icing salt, is the most common mechanism [5,6]. Neither of these mechanisms directly attack the concrete itself - rather, the aggressive species are transported through the pore system of the concrete and attack the embedded steel. This ability of carbon dioxide and chloride ions to penetrate concrete without notably damaging it is in contrast to the more usual degradation mechanisms due to chemical attack on concrete by other acids and aggressive ions such as sulphate, which undermine the integrity of the concrete itself before the steel is attacked. Hence, most forms of chemical attack constitute issues with the concrete itself before they become corrosion issues. Reports of corrosion of steel rebars in concrete due to acid rain remain unproven; only carbon dioxide and chloride ion have been demonstrated to attack the steel rebars while not damaging the concrete [7]. Chloride ions penetrate the hardened concrete cover to arrive at the surface of the steel rebar, where breakdown of the passive film takes place as soon as the chloride concentration passes a critical value. This is known as the chloride threshold level (CTL) and is usually defined in two ways: scientists define the CTL as the chloride content required for depassivation of the steel reinforcement, while engineers frequently define the CTL as the chloride content associated with visible or acceptable deterioration of the reinforced concrete structures. The service life of concrete structures exposed to chloride environments is strongly dependent upon the CTL [8]. Following initiation of corrosion, propagation of the process can lead to the development and accumulation of insoluble corrosion products (rust) around the reinforcing steel. Rust expansion generates pressure which can lead to serious damage to reinforced concrete structures, including spalling, delamination, and cracking of the concrete cover [9]. Poor performance of the concrete can also arise due to one or more of the following: poor design, poor construction, inappropriate materials selection, or a more ag gressive environment than 


\section{International Journal of Current Science Research and Review}

ISSN: 2581-8341

Volume 04 Issue 02 February 2021

DOI: 10.47191/ijcsrr/V4-i2-04, Impact Factor: 6.825

IJCSRR@ 2021

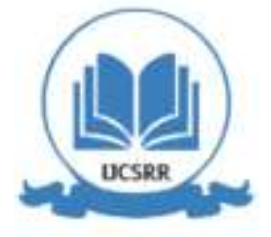

www.ijcsrr.org

expected. Hence, the corrosion of steel rebars in concrete is a significant challenge for civil engineers and construction workers in their efforts to conserve an ageing infrastructure [10]. According to Tiwari et al. [11], every aspect of industrial infrastructure in the United States and worldwide is affected by corrosion repair, maintenance and replacement costs, both in terms of environmental damage and in terms of serious structural damage leading to public safety issues. In the United States alone, an estimated annual cost of $\$ 300$ billion U.S. dollars, almost 3.1\% of gross domestic product (GDP), is attributed directly to corrosion. This suggests that corrosion costs for the industrialised world as a whole would be in the region of $\$ 2.2$ trillion U.S. dollars - more than $3 \%$ of the world's GDP. The published literature during the last fifty years has broadly covered the protection methodology to address this issue and the use of specially designed low-permeability concrete has been monitored since 1970 [12]. Alongside this, the major area of investigation has been the development, limitations and efficiency of electrochemical rehabilitation techniques, in particular cathodic protection systems including impressed current or sacrificial anode [13]. The use of patch repairs, coatings, sealing and membranes for concrete surface, special steel bar (stainless steel bar, epoxy coated steel reinforcement, galvanized steel reinforcing bars) and corrosion inhibitors for reinforced concrete have also been reported in the literature [14-16]. Corrosion inhibitors are regarded among the most efficient and long-term corrosion protection methodologies for steel reinforcements. Their ease of handling (as mixed-in or migrate-through components) and their low cost compared with cathodic protection make their use particularly desirable [17]. However, it is clearly indicated on the containers, the traditional inhibitors are toxic and extremely hazardous to human health. These hazards are indicated by the following indices:

i. The biological oxygen demand (BOD) is a measure of how long an inhibitor will persist in the environment. According to environmental legislation, the biodegradation or biological oxygen demand (BOD), should be at least $60 \%$, and inhibitors should be nontoxic.

ii. Toxicity can be measured as the $\mathrm{LC}_{50}$, which is the concentration of the inhibitor needed to kill one half of the test population. The results are quoted as milligrams of chemical per litre of fluid (or $\mathrm{LD}_{50}$, milligrams per kilogram) for exposure times of 24 and $48 \mathrm{~h}$.

iii. An alternative measure is the $\mathrm{EC}_{50}$, which is the effective concentration of inhibitor that will adversely affect one half of the test population. Since the $\mathrm{EC}_{50}$ indicates the concentration levels that will cause harm to a species without causing fatality, this value tends to be lower than the $\mathrm{LC}_{50}$.

Hence it becomes imperative to review the current inhibitors in order to find more appropriate, suitable, and sustainable inhibitor.

\section{MECHANISM OF PROTECTION}

\section{Inorganic Inhibitors}

The most commonly applied method is the addition of inhibitors to the mixing water for new concrete structures with the aim of preventing or at least delaying the initiation of corrosion. Inorganic inhibitors can act by either an anodic mechanism (e.g. benzoate, chromate, molybdate, nitrite, orthophosphate, silicate, tungstate) or a cathodic mechanism via ions such as magnesium, nickel or zinc, which react with the hydroxyl ion $\left(\mathrm{OH}^{-}\right)$present in water to form insoluble hydroxides such as $\mathrm{Mg}(\mathrm{OH})_{2}, \mathrm{Ni}(\mathrm{OH})_{2}, \mathrm{Zn}(\mathrm{OH})_{2}$, as well as polyphosphates, or aminoethylene phosphates [18, 19]. The effectiveness of calcium nitrite-based corrosion inhibitors, and their impact upon chloride transport, compressive strength and setting time of concrete, have investigated by Ann et al. [20] using a polarisation technique. Whereas the nitrite-free specimen in chloride-contaminated mortar showed a chloride threshold level of $0.18 \%$ to $0.33 \%$, the calcium nitrite-based corrosion inhibitor lowered the corrosion rate of the steel and raised the chloride threshold level to between $0.22 \%$ and $1.95 \%$ by weight of cement. A rapid test for chloride ion permeability indicated that that concrete specimens containing the corrosion inhibitor transferred the higher total charge. The concrete setting time was shown to decrease as the dosage of corrosion inhibitor increased. In the short term, the compressive strength of the concrete was enhanced by the corrosion inhibitor but, after 900 days, the compressive strength diminished to the level that was noted at 28 days. Lee and Shin: [19] investigated the effect of lithium nitrite corrosion inhibitor by the corrosion sensors embedded in mortar. The researchers deduced that mortar containing chlorides, an effective dosage of lithium nitrite corrosion inhibitor is 0.6 or more in the nitritechloride ion molar ratio $\left(\mathrm{NO}_{2}^{-}=\mathrm{Cl}^{-}\right)$. When the ratio of the measured sensor resistance $(\mathrm{R})$ to the initial resistance $\left(\mathrm{R}_{\mathrm{o}}\right)$ increases from 2 to 4, corrosion in a corrosion sensor begins. The best way to non-destructively monitor the onset time and degree of corrosion in reinforcement bars is by measuring the electrical resistance of corrosion sensors $(\mathrm{R})$ and also calculating the corrosion area percentage $\left(\mathrm{A}_{\text {cor }}\right)$ using the correlation between $\mathrm{R} / \mathrm{R}_{\mathrm{o}}$ and $\mathrm{A}_{\text {cor }}$. The impact of potassium-chromate $\left(\mathrm{K}_{2} \mathrm{CrO}_{4}\right)$ and sodium nitrite $\left(\mathrm{NaNO}_{2}\right)$ on the degradation of steel rebar in sulphuric acid and in sodium chloride media has been examined by Okeniyi et al. [18] 


\section{International Journal of Current Science Research and Review}

ISSN: 2581-8341

Volume 04 Issue 02 February 2021

DOI: 10.47191/ijcsrr/V4-i2-04, Impact Factor: 6.825

IJCSRR@ 2021

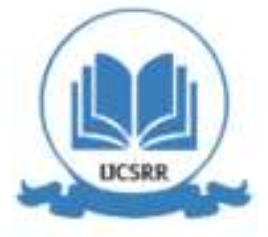

www.ijcsrr.org

the concrete admixed with $0.679 \mathrm{M}$ sodium nitrite showed the best inhibition efficiency in the saline medium, although there was a reduction in the compressive strength of the concrete. In the acidic medium, the concrete admixed with $0.145 \mathrm{M}$ potassium chromate showed the best inhibition efficiency and afforded a good improvement in compressive strength. Lee et al. [21] investigated the ability of lithium nitrite inhibitor to provide corrosion protection to reinforcing steel. The following conclusions can be drawn:

1. The results of this study indicated that the lithium nitrite inhibitor most strongly exhibited corrosion-protection properties at a molar ratio of 0.6 and above.

2. The lithium nitrite inhibitor secured anti-corrosion capacity at chloride ion levels of $2.4 \mathrm{~kg} / \mathrm{m}^{3}$ and $4.8 \mathrm{~kg} / \mathrm{m}^{3}$; corrosion was low at molar ratio of inhibitor of $\geq 1.2$.

3. Water-soluble chloride content only slightly varied as the amount of the lithium nitrite corrosion inhibitor increased.

4. Through the effect of binding chloride ions, the lithium nitrite inhibitor showed fewer anti-corrosion effects in saline environments.

According to Yohai et al. [22] they summarised the performance of sodium biphosphate $\left(\mathrm{Na}_{2} \mathrm{HPO}_{4}\right)$ as corrosion inhibitor for construction steel in three inhibitive solutions (IS20, IS60 and IS100) as follow:

1. When phosphate is incorporated, a passive behaviour is found, as shown by nobler $\mathrm{E}_{\text {corr }}$ values, non-linear $\mathrm{R}_{\mathrm{p}}$ curves and EIS results. Ferrous phosphate precipitation could be responsible for these changes, as detected by Raman spectroscopy and XPS. Due to the low carbonation degree in IS100, Fe dissolution could be favoured, followed by immediate precipitation of ferrous phosphate on the steel surface.

2. After $24 \mathrm{~h}$ at open circuit potential in contact with biphosphate ions, impedance spectra show two time constants with high $\mathrm{R}_{\mathrm{o}}$ and $\mathrm{R}_{\mathrm{t}}$ values, confirming the presence of a passive film that controls the corrosion process. This film becomes more protective in the case of IS100.

3. Also, as the $\left[\mathrm{HPO}_{4}^{2-}\right] /\left[\mathrm{Cl}^{-}\right]$ratio increases, so does the difference $\left(\mathrm{E}_{\mathrm{pic}}-\mathrm{E}_{\mathrm{corr}}\right)$, which proves a better resistance to localized attack for the highest inhibitor dosage. However, no repassivation was detected.

4. After over one month in immersion, steel remains passive in the condition IS100, with an inhibition factor higher than $99 \%$. In contrast, in the case of IS60 and IS 20, pitting was detected.

The Effect of $\mathrm{LiNO}_{2}$ inhibitor on corrosion characteristics of steel rebar in saturated $\mathrm{Ca}(\mathrm{OH})_{2}$ solution containing $\mathrm{NaCl}$ was investigated by Ryu et al. [23], the following conclusions can be drawn:

i. $\mathrm{LiNO}_{2}$ inhibitor significantly reduces the corrosion of steel rebar in saturated $\mathrm{Ca}(\mathrm{OH})_{2}$ solution with different contents of $\mathrm{NaCl}$.

ii. $\mathrm{LiNO}_{2}$ inhibitor works as mixed type corrosion inhibitor which reduced the corrosion of steel rebar in $\mathrm{Cl}^{-}$ion containing alkaline solution by forming stable iron oxides.

iii. EIS studies explained the process of adsorption of $\mathrm{LiNO}_{2}$ inhibitor on steel surface by formation of capacitive passive film.

iv. The efficiency of $\mathrm{LiNO}_{2}$ inhibitor in different concentration of $\mathrm{NaCl}$ was calculated and it is $63.67 \%$ in $0.99 \mathrm{~g} / \mathrm{L} \mathrm{NaCl}$ at $\left[\mathrm{Cl} / \mathrm{NO}_{2}\right]=0.6$. As the concentration of $\mathrm{NaCl}$ is increased the efficiency is decreased.

v. Potentiodynamic results revealed that as inhibitor content is increased in saturated $\mathrm{Ca}(\mathrm{OH})_{2}$ solution with different concentrations of $\mathrm{NaCl}$, fluctuated anodic curve is observed attributed owing to formation of meta-stable potential and new phase of stable iron oxides.

\section{Organic Inhibitors}

Organic inhibitors tend to be mixed inhibitors, displaying both anodic and cathodic actions in tandem, and are exceptionally effective inhibitors due to the presence of heteroatoms such as oxygen, nitrogen and sulphur and the presence of multiple bonds in their molecules, all of which facilitate adsorption onto the metal surface [24-26]. According to Ali [27], they decrease the corrosion rate by: (i) increasing or decreasing the anodic and/or cathodic reaction, (ii) decreasing the rate of diffusion of reactants to the metal surface, and (iii) decreasing the electrical resistance of the metal surface. The effectiveness of an amino-alcohol based corrosion inhibitor was investigated by Benzima Mechmech et al. (2008). They used simulated pore solutions as well as mortar specimens. Based on the facts of the experiment, the following deductions can be made: [28]

i. The primary aim of the investigation was to check the most efficient mode of use of an amino-based mixed corrosion inhibitor in two distinct cases of simulating solutions and real mortar specimens. 


\section{International Journal of Current Science Research and Review}

ISSN: 2581-8341

Volume 04 Issue 02 February 2021

DOI: 10.47191/ijcsrr/V4-i2-04, Impact Factor: 6.825

IJCSRR@ 2021

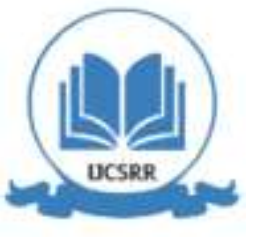

www.ijcsrr.org

ii. The researchers aptly carried out the tests in simulated pore solutions in order to obtain a rapid result. In this instance, the inhibitor demonstrated some inhibitive action the moment it was introduced before the chlorides.

iii. The inhibitor was apparently effective in the case of mortar specimens, even with the presence of chlorides. This is different from the case of simulated pore solutions. It is reasonable to deduce that the curative method of usage is effective because the inhibitor reacted against existing corrosion. It became possible to slow down its progression in both cases of presence and absence of chlorides.

iv. The environment and the way of use significantly impacted the efficiency of the inhibitor. The dilution of the inhibitor at 1 $\mathrm{ml} / 50 \mathrm{ml}$ in water is a reasonably suitable mean. It can insure diffusion in the case of mortar specimens with a standard mix.

Another researcher (Ormellese et al.[29], evaluated the impact of aminic and carboxylic groups as candidate inhibitors for reinforcement corrosion in chlorides containing concrete. Based on his research, the following deductions can be made:

1. Amines demonstrated poor inhibition effect. When the volatility of amines is increased, they demonstrated very scattered result.

2. Even though aminoacids demonstrated some inhibition effect, it was not sufficient for any industrial application.

3. Among the tested substances, carboxylate substances, in particular poly-carboxylates proved to be the most promising candidates because they displayed very good inhibition efficiency. It is necessary to check compatibility of concrete slab specimens with concrete in order to confirm long-term effectiveness.

A strong link between molecular structure and inhibiting properties was established in the case of carboxylate substances. The following factors influence the inhibition action.

i. The electron-donor effect or the electron attractor; an electron-donor substituent that gives up electrons and promotes the process of adsorption via negative charge localization carboxylic group and on oxygen. Adsorption is a process that combines resonance and inductive effect on the electron density of a molecule. Inversely, an electron attractor is a high electronegative substituent which weakens the process of adsorption because electrons are not available for it.

ii. The electrostatic effect is another factor. This happens when adsorbed molecules with a negatively charged substituent or a lone pair electrons develop a repulsive action towards chloride ions, avoiding chloride to be in contact with the carbon steel passive layer.

iii. The steric effect is when Alkylic chain or voluminous substituent groups form a sort physical barrier that blocks or delay chloride arrival to the metal surface.

iv. Some repulsion effect between adsorbed molecules is possible, because of the presence of highly polar group, a process known as lateral interaction effect.

Another researcher (Diamanti et al. [30]), assessed the interaction processes between the passive film of carbon steel in a chloriderich alkaline environment and five organic inhibitors. The researcher established that the Tartrate portrayed the best inhibitive behaviour because of its excellent surface coverage, adsorption strength, and the repulsive effect put on chlorides by the exposed carboxylate anions. Another element, Benzoate also showed a reliable adsorption energy as well as uniform distribution when adsorbing on $\gamma$-FeOOH. This is specifically crucial to the production of efficient inhibition. Glutamate, too, demonstrated the highest calculated adsorption among the anionic inhibitors. It showeda carboxylate distribution that is the same as the tartrate, factors which allowed it to reach a high pitting potential. Amines show poor inhibition effect due to their poor repulsive interaction with chloride ions. This confirms the experimental evidence and documentation of this work and also previous ones. Fundamentally, it is possible to confirm the favourable interaction energy between the adsorbed molecules and $\gamma$-FeOOH surface, with the onset of repulsive intermolecular interactions among anions. Based on the observation it is reasonable to deduce that molecular dynamics and molecular mechanics confirm to be an additional, powerful tool, key to understanding the behaviour of inhibitors in the availability of a bare or passivated metallic surface, and also to foresee their possible efficiency in inhibiting steel corrosion in the chosen environmental conditions. A number of researchers have studied the effectiveness of N-heterocyclic organic compounds and their derivatives [31-38]. These groups have made use of techniques including gravimetrics, potentiodynamic polarisation, electrochemical impedance spectroscopy, scanning electron microscopy, quantum chemical calculation, and analytical approaches to support their conclusions. Due to adsorption onto the metal surface, which follows the Langmuir isotherm adsorption model, the 


\section{International Journal of Current Science Research and Review}

ISSN: 2581-8341

Volume 04 Issue 02 February 2021

DOI: 10.47191/ijcsrr/V4-i2-04, Impact Factor: 6.825

IJCSRR@ 2021

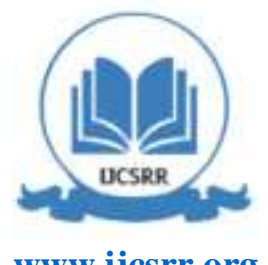

www.ijcsrr.org

N-heterocyclic organic compounds were found to be effective corrosion inhibitors for mild steel subjected to acid and chloride environments.

\section{Sealers and Barriers and Inhibitors}

The corrosion properties of five corrugated stainless steel bars in carbonated mortars UNS S20430, S30400, S31603, S31635 and S32205 have assessed by Bautista et al. [39]. Three different exposure conditions were studied, namely: (i) high relative humidity (C-HRH), (ii) partial immersion in $3.5 \% \mathrm{NaCl}\left(\mathrm{C}-\mathrm{PI}\right.$ ), and (iii) with $\mathrm{CaCl}_{2}$ added during mortar mixing followed by exposure to high relative humidity $(\mathrm{C}-\mathrm{HRHCl})$ for 9 years. The authors concluded that the $\mathrm{S} 20430$ corrugated bars were particularly vulnerable to a low-intensity corrosive attack in carbonated mortars in the presence of chloride and that the corrosion rate can readily increase in response to moderate anodic polarisation. It was also noted that, during partial immersion in $3.5 \% \mathrm{NaCl}$, corrosion of the $\mathrm{S} 20430$ reinforcements progressed more rapidly in carbonated mortars than in non-carbonated ones, in spite of the reduced quantity of diffused chlorides in the former. The duplex S32205 was found to be completely resistant to corrosion in the carbonated mortar in the presence of chlorides, even when partially immersed and subjected to high anodic polarisation. Finally, the austenitic stainless steel reinforcements were vulnerable to localised corrosion in carbonated mortar in the presence of chlorides when subjected to high anodic polarisation. The influence of impressed current cathodic protection (ICCP) upon the corrosion of reinforced concrete structures has investigated by Qiao et al., [40] indicating that the technique can effectively control the corrosion of the reinforcing steel, as well as demonstrating that the junctions between the longitudinal steel and stirrup or transverse steel are the most difficult to protect, while a steel bar closer to the anode is more readily protected.

A number of groups [41-45] have examined the impact of chloride ingress upon concretes containing natural zeolite (NZ), metakaolin, fly ash (FA) and silica fume (SF) during exposure to aggressive marine conditions. It has demonstrated that the FA concrete has equal compressive strength (fc) values to the reference concrete, both at early (7 days) and late (28 days) ages, while subsequently, the composite concretes show higher strengths than the OPC concrete. This result is related to the observed low porosity of FA concrete. It has also shown that the use of silica fume and natural zeolite significantly improves the resistance of concrete mixtures to chloride diffusion, with the control mixture showing the highest chloride diffusion coefficient and the greatest depth of chloride penetration of all the mixtures for all exposure temperatures. For the same replacement level, the enhancing effect of SF was more significant than that of NZ, while the performance of NZ in terms of enhancing the durability of concrete in a harsh environment was generally similar to that of metakaolin and silica fume. Finally, all mixtures incorporating SF or NZ showed lower activation energy than the control mixture. Thus, increased temperature of exposure has less effect upon the increase in chloride diffusion coefficient for concrete mixtures containing silica fume or NZ than for the control concrete mixtures.

\section{Green Corrosion Inhibitors}

The green corrosion inhibition properties of various concentrations of Vernonia amygdalina (bitter leaf) extract upon steel rebar embedded in concrete and exposed to 3.5\% sodium chloride solution was examined by Loto et al. [46]. The variation in inhibitor concentration $(25,5075$, and $100 \%)$ and in exposure time were found to notably influence both the corrosion potential of the embedded steel and the $\mathrm{pH}$ of the solution. While the bitter leaf extract afforded fair corrosion inhibition at concentrations of $50 \%$ and $75 \%$, the best inhibition (90.08\%) was obtained at the lowest inhibitor concentration examined (25\%). The influence of Vernonia amygdalina as a corrosion inhibitor for carbon steel reinforced concrete in 3.5\% sodium chloride solution has also investigated by Eyu et al. [47]. This group demonstrated that within 70 days of immersion the plant extract gave an outstanding $\mathrm{E}_{\text {corr }}$ value of +95 $\mathrm{mV}$, compared with a value of $+85 \mathrm{mV}$ for calcium nitrite at a concentration of $12 \mathrm{~L} . \mathrm{m}^{-3}$. Although the $2 \%$ (wt.) sodium nitrite falls within $+126 \mathrm{mV}$ at the end of the study, this work demonstrates that the green inhibiter can be applied to the corrosion inhibition of steel reinforcements in concrete exposed to a chloride-rich environment. The authors also noted that, during the period of immersion, the reduction in the rate of corrosion for steel in concrete was better in the presence of the plant extract than in the presence of calcium or sodium nitrite. The effect of admixtures containing various concentrations of Anthocleista djalonensis leaf extract for corrosion inhibition of steel reinforcements in concrete during exposure to a simulated saline/marine environment (immersion in $3.5 \% \mathrm{NaCl}$ solution) was investigated by Okeniyi et al. [48]. The results were analysed to demonstrate that the corrosion rate was inversely proportional to the cube of the ratio of standard deviations of corrosion potential and corrosion current and directly proportional to the admixture concentration. While high corrosion inhibition for the steel reinforcements were achieved for a range of admixture concentrations, the best inhibition efficiency (IE\% $=97.43 \pm 1.20 \%$ according to the experimental data analysis and $94.80 \pm 3.39 \%$ according to the correlation model prediction) was obtained at a leaf extract concentration of $0.4167 \%$. Isotherm 


\section{International Journal of Current Science Research and Review}

ISSN: 2581-8341

Volume 04 Issue 02 February 2021

DOI: 10.47191/ijcsrr/V4-i2-04, Impact Factor: 6.825

IJCSRR @ 2021

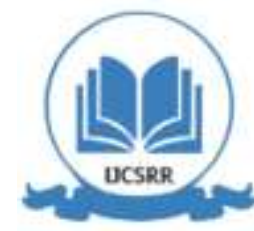

www.ijcsrr.org

fittings of both the experimental data and model behaviour suggest that they follow the Langmuir adsorption model. The parameters from the isotherm model were evaluated to indicate favourable adsorption, mainly by a chemisorption mechanism, of this green corrosion inhibitor for steel reinforcements in the simulated saline/marine environment. A study by Asipita et al. [49] demonstrated that the water permeability resistance of reinforced concrete treated with the environmentally friendly inhibitor (Bambusa arundinacea) fulfilled the requirements of the ISAT standard for low permeability concrete, giving values of less than $0.25 \mathrm{~mL} . \mathrm{m}$ 2 after $10 \mathrm{~min}, 0.17$ mL.m-2 after $30 \mathrm{~min}, 0.10 \mathrm{~mL} . \mathrm{m}-2$ after 1 hour, and $0.07 \mathrm{~mL} . \mathrm{m}-2$ after 2 hours. The influence of the leafextract of Morinda lucida upon the corrosion and degradation behaviour of steel-reinforced concrete during exposure to a simulated marine/saline environment (3.5\% NaCl solution) was examined by Okeniyi et al. [50]. The results demonstrated that the use of the leaf extract in admixtures for steel-reinforced concretes afforded highly effective corrosion inhibition $(84.82 \pm 7.76 \%$, IE\% $=95.64$ $\pm 1.50 \%$ ) along with favourable improvements in compressive strength. This is a significant result for the corrosion protection of offshore wind-energy structures and installations which are typically subject to saline/marine conditions. The corrosion inhibition and compressive strength impact upon steel-reinforced concrete due to the leaf extract Rhizophora mangle L. has investigated by Asaad et al. [51] during exposure to a simulated industrial environment $\left(0.5 \mathrm{M} \mathrm{H}_{2} \mathrm{SO}_{4}\right)$ relevant to certain wind-energy installations. The admixtures afforded both good corrosion inhibition and good compressive strength improvements, the optimum inhibition efficiency being obtained for an extract concentration of $0.1667 \%$ by weight of cement. Okeniyi et al. [52] investigated the prospects of Phyllanthus muellerianus as eco-friendly/sustainable material for reducing concrete steel reinforcement corrosion in industrial/microbial environment. It was found that Phyllanthus muellerianus is constituted of non-toxic level of inorganic/heavy metals, useful phytochemical constituents, and essential heteroatoms that makes it potent with excellent reduction effects on the total-corrosion model of steel-reinforcement in concrete immersed in the industrial/microbial simulating-environment studied. The corrosion behaviour of steel reinforcements in concrete during various times of exposure to $3.5 \% \mathrm{NaCl}$ solution in the presence and absence of Prosopis juliflora extract has been investigated by Palanisamy et al. [53]. This work demonstrated that adsorption of inhibitor onto the surface of the embedded steel followed the Temkin isotherm and that the extract acted as a corrosion inhibitor by forming a protective surface layer and by influencing the reactions at both the cathodic and anodic sites on the steel

\section{Green Nanoparticles Inhibitors}

In recent times nanomaterials, which are usually defined as materials consisting of particles less than $100 \mathrm{~nm}$ in size, have drawn a significant amount of attention due to their extraordinary properties, e.g. surface and quantum confinement effects, and have made nanotechnology a fast-growing and fascinating subject [54]. Dhand et al. [55] have cited a large body of literature dealing with the varied applications of nanoparticles of precious metals such as gold, platinum and silver in the fields of electronics, magnetism, optical receptors and catalysis. The desirable optical properties of these precious metals are the consequence of a phenomenon known as surface plasmon resonance (SPR), i.e. the concerted excitation of free-electron gas resulting in intense absorption in the visible region. Silver nanoparticles (AgNPs) have become particularly significant because of their powerful applications in biolabelling, nonlinear optics, optical receptors, solar energy absorption, as intercalation materials in electrical batteries and as catalysts for a wide range of chemical reactions. The scope of these particles is further extended by their powerful antimicrobial activity against a range of micro-organisms, making them applicable to the treatment of burns, the prevention of bacteria colonisation on medical devices and dental materials and the eradication of microorganisms in fabrics, as well as for water treatment and as coatings for stainless steel materials [56-58]. A wide range of techniques have been developed for the synthesis of AgNPs, including: (i) physical methods such as microwave radiation, ultrasonic irradiation, radiolysis and photochemical synthesis, (ii) chemical methods including chemical reduction and electrochemical synthesis, and (iii) biological methods involving microorganisms, plant extracts and biomolecules [59]. The most frequently used methodology is chemical synthesis because it allows the easy and efficient production of small, uniform and highly dispersed nanoparticles. The disadvantages of this approach are: (i) the need for toxic chemicals to act as reducing agents and/or capping substances, (ii) most methods are multi-step syntheses leading to high energy usage, low material conversion, purification problems, and the further use of hazardous chemicals possibly leading to the presence of surface-adsorbed toxic chemicals which may have adverse effects during end use. Finally, (iii) the rising number and variety of applications have resulted in increased human exposure to silver nanoparticles. According to Kummara et al. [60] silver nanoparticles administered either orally, by inhalation or subcutaneously have been demonstrated pass into the blood circulation and become concentrated in certain organs, leading to hepatotoxicity or renal toxicity. These drawbacks of chemical reduction has resulted in the emergence of biosynthesis, using extracts from natural products, as a facile, economical and environmentally sound 


\section{International Journal of Current Science Research and Review}

ISSN: 2581-8341

Volume 04 Issue 02 February 2021

DOI: 10.47191/ijcsrr/V4-i2-04, Impact Factor: 6.825

IJCSRR@ 2021

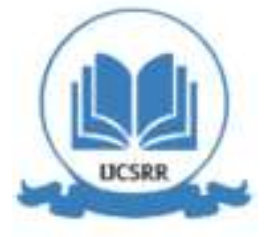

www.ijcsrr.org

alternative to the chemical synthesis of nanoparticles. This approach avoids not only the use of hazardous materials for reducing or capping agents but also the production of hazardous waste [61]. Nevertheless, the literature includes only a few examples of research using AgNPs, in conjunction with other materials such as poly 12-(3-amino phenoxy) dodecane-1-thiol [62], Poly(methacrylic acid) [63] and polypropylene glycol [64] for the corrosion inhibition of mild steel in aggressive media. Further potential applications of nanoparticles include their use as nuclei for cement phases, to enhance cement hydration via their high reactivity, as nano-scale reinforcements, and as fillers to increase the density of the microstructure and the interfacial transition zone (ITZ), leading to decreased porosity. For all nanoparticles, effective dispersion is the major challenge. The utilisation of a corrosion inhibitor extracted from the Elaeis guineensis (EG) plant, combined with synthesis of silver nanoparticles (AgNPs) to produce a green nanoparticles corrosion inhibitory compound (EG/AgNP) applicable to reinforcement steel bars in aggressive environments represents an innovative feature of this work.

\section{CONCLUSION}

The foregoing literature survey raises the following points:

a. Although a long history of research has proven the effectiveness of stainless steel reinforcements for the enhancement of coastal bridge service life, the use of expensive stainless steel rebars, rather than carbon steel bars, adds a $10 \%$ surcharge to the total project costs.

b. Although investigations into the application of carbon-fibre reinforcements have indicated that they are not subject to corrosion, they do not present an ideal solution since there is a potential degradation process involving hydrolysis of the glass and aramid fibres. This is particularly likely in the highly alkaline concrete and will result in loss of durability.

c. Cathodic protection has been demonstrated effective for the protection of steel reinforcements in concrete. The approach can have drawbacks, however, especially during the application of an impressed current, since the system is highly expensive to set up, run and maintain. Furthermore, fuses may blow and switches may be unintentionally turned off, hence the need for more frequent monitoring of the system, and the process can generate stray currents which lead to corrosion of nearby structures and to the formation of micro-cracks in concrete.

d. The mechanical properties of concrete could be enhanced by the use of additives such as fly ash, metakaolin, natural zeolite, or silica fume. However, the drawbacks of this approach include not only poor concrete workability but also comparatively high levels of surface water absorption due to the presence of fine capillary pores. This can lead to reduced durability of concrete in the tidal or splash zone of marine concrete structures where there is the potential for a significant build-up of chloride and sulphate.

e. Although the use of barriers such as water-proofing membranes and sealers was found to be effective in forestalling corrosion, there was a need for continual maintenance and re-application during the service life of the structure.

f. The bond between the concrete and the steel rebar is an important design factor for reinforced concrete, relating to the transmission of force between the concrete and rebar. In this context, the main issue with the use of epoxy coated rebar is the resultant compromise of the concrete-rebar bond, leading to the potential for significant levels of chloride attack and for localised corrosion.

g. As well as a reduction in the rate of corrosion, the use of green inhibitors has shown to afford enhanced compressive strength, decreased concrete permeability, and increased concrete durability compared with commercially available inhibitors. However, in comparison to nanomaterials, the large size of green inhibitors means they cannot function as fillers to reduce concrete porosity, and their low reactivity causes a reduction in cement hydration. Additionally, it has been demonstrated that the addition of nano-particle fillers into coatings, even at low concentrations, affords greatly improved barrier properties compared to traditional micron sized additives.

\section{ACKNOWLEDGEMENTS}

The authors are thankful to Iraq University College for supporting this research.

\section{REFERENCES}

1. A. Michel, M. Otieno, H. Stang, M.R. Geiker, Propagation of steel corrosion in concrete: Experimental and numerical investigations, Cement and Concrete Composites 70 (2016) 171-182. 
ISSN: 2581-8341

Volume 04 Issue 02 February 2021

DOI: 10.47191/ijesrr/V4-i2-04, Impact Factor: 6.825

IJCSRR@ 2021

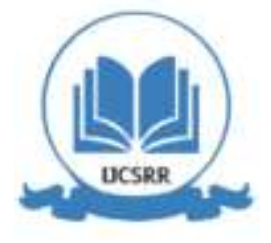

www.ijcsrr.org

2. G. Duffó, S. Farina, C. Giordano, Characterization of solid embeddable reference electrodes for corrosion monitoring in reinforced concrete structures, Electrochimica Acta 54(3) (2009) 1010-1020.

3. M.A. Asaad, M. Ismail, M.M. Tahir, G.F. Huseien, P.B. Raja, Y.P. Asmara, Enhanced corrosion resistance of reinforced concrete: Role of emerging eco-friendly Elaeis guineensis/silver nanoparticles inhibitor, Construction and Building Materials 188 (2018) 555-568.

4. M.G. Stewart, X. Wang, M.N. Nguyen, Climate change adaptation for corrosion control of concrete infrastructure, Structural Safety 35 (2012) 29-39.

5. C. Lu, S. Yuan, P. Cheng, R. Liu, Mechanical properties of corroded steel bars in pre-cracked concrete suffering from chloride attack, Construction and Building Materials 123 (2016) 649-660.

6. Y.S. Choi, S.-T. Yi, M.Y. Kim, W.Y. Jung, E.I. Yang, Effect of corrosion method of the reinforcing bar on bond characteristics in reinforced concrete specimens, Construction and Building Materials 54 (2014) 180-189.

7. M.A. El-Reedy, Reinforced concrete structural reliability, CRC Press2012.

8. I. Ustabas, The effect of capillarity on chloride transport and the prediction of the accumulation region of chloride in concretes with reinforcement corrosion, Construction and Building Materials 28(1) (2012) 640-647.

9. C. Cao, M.M. Cheung, Non-uniform rust expansion for chloride-induced pitting corrosion in RC structures, Construction and Building Materials 51 (2014) 75-81.

10. Z.A. Etman, Reinforced Concrete Corrosion and Protection, Concrete Research Letters 3(1) (2012) 359-372.

11. A. Tiwari, L. Hihara, J. Rawlins, Intelligent coatings for corrosion control, Butterworth-Heinemann2014.

12. M. Khan, M. Ali, Use of glass and nylon fibers in concrete for controlling early age micro cracking in bridge decks, Construction and Building Materials 125 (2016) 800-808.

13. J.-H. Kim, Y.-S. Kim, J.-G. Kim, Cathodic protection criteria of ship hull steel under flow condition in seawater, Ocean Engineering 115 (2016) 149-158.

14. E. Cadoni, L. Fenu, D. Forni, Strain rate behaviour in tension of austenitic stainless steel used for reinforcing bars, Construction and Building Materials 35 (2012) 399-407.

15. M. Conradi, A. Kocijan, D. Kek-Merl, M. Zorko, I. Verpoest, Mechanical and anticorrosion properties of nanosilica-filled epoxy-resin composite coatings, Applied Surface Science 292 (2014) 432-437.

16. F. Tittarelli, G. Moriconi, The effect of silane-based hydrophobic admixture on corrosion of galvanized reinforcing steel in concrete, Corrosion Science 52(9) (2010) 2958-2963.

17. F.-1. Fei, J. Hu, J.-x. Wei, Q.-j. Yu, Z.-s. Chen, Corrosion performance of steel reinforcement in simulated concrete pore solutions in the presence of imidazoline quaternary ammonium salt corrosion inhibitor, Construction and Building Materials 70 (2014) 43-53.

18. J.O. Okeniyi, O.A. Omotosho, O.O. Ajayi, C.A. Loto, Effect of potassium-chromate and sodium-nitrite on concrete steelrebar degradation in sulphate and saline media, Construction and Building Materials 50 (2014) 448-456.

19. H.-S. Lee, S.-W. Shin, Evaluation on the effect of lithium nitrite corrosion inhibitor by the corrosion sensors embedded in mortar, Construction and Building Materials 21(1) (2007) 1-6.

20. K.Y. Ann, H.S. Jung, H.S. Kim, S.S. Kim, H.Y. Moon, Effect of calcium nitrite-based corrosion inhibitor in preventing corrosion of embedded steel in concrete, Cement and Concrete Research 36(3) (2006) 530-535.

21. H.-S. Lee, H.-S. Ryu, W.-J. Park, M.A. Ismail, Comparative study on corrosion protection of reinforcing steel by using amino alcohol and lithium nitrite inhibitors, Materials 8(1) (2015) 251-269.

22. L. Yohai, W. Schreiner, M. Vázquez, M. Valcarce, Phosphate ions as effective inhibitors for carbon steel in carbonated solutions contaminated with chloride ions, Electrochimica Acta 202 (2016) 231-242.

23. H.-S. Ryu, J.K. Singh, H.-S. Lee, M.A. Ismail, W.-J. Park, Effect of LiNO 2 inhibitor on corrosion characteristics of steel rebar in saturated $\mathrm{Ca}(\mathrm{OH}) 2$ solution containing $\mathrm{NaCl}$ : An electrochemical study, Construction and Building Materials 133 (2017) 387-396.

24. K.K. Alaneme, S.J. Olusegun, O.T. Adelowo, Corrosion inhibition and adsorption mechanism studies of Hunteria umbellata seed husk extracts on mild steel immersed in acidic solutions, Alexandria Engineering Journal 55(1) (2016) 673681. 


\section{International Journal of Current Science Research and Review}

ISSN: 2581-8341

Volume 04 Issue 02 February 2021

DOI: 10.47191/ijcsrr/V4-i2-04, Impact Factor: 6.825

IJCSRR @ 2021

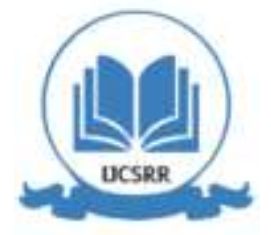

www.ijcsrr.org

25. M. Faustin, A. Maciuk, P. Salvin, C. Roos, M. Lebrini, Corrosion inhibition of C38 steel by alkaloids extract of Geissospermum laeve in 1M hydrochloric acid: Electrochemical and phytochemical studies, Corrosion Science 92 (2015) 287-300

26. E. Kowsari, M. Payami, R. Amini, B. Ramezanzadeh, M. Javanbakht, Task-specific ionic liquid as a new green inhibitor of mild steel corrosion, Applied Surface Science 289 (2014) 478-486.

27. A.I. Ali, Melia azedarach L as eco- friendly corrosion inhibitor for Aluminum in $2 \mathrm{M} \mathrm{HCl}$, Journal of Materials and Environmental Science 5(3) (2014) 793-802.

28. L. Benzina Mechmeche, L. Dhouibi, M. Ben Ouezdou, E. Triki, F. Zucchi, Investigation of the early effectiveness of an amino-alcohol based corrosion inhibitor using simulated pore solutions and mortar specimens, Cement and Concrete Composites 30(3) (2008) 167-173.

29. M. Ormellese, L. Lazzari, S. Goidanich, G. Fumagalli, A. Brenna, A study of organic substances as inhibitors for chlorideinduced corrosion in concrete, Corrosion Science 51(12) (2009) 2959-2968.

30. M. Diamanti, E.P. Rosales, G. Raffaini, F. Ganazzoli, A. Brenna, M. Pedeferri, M. Ormellese, Molecular modelling and electrochemical evaluation of organic inhibitors in concrete, Corrosion Science 100 (2015) 231-241.

31. K. Zakaria, N.A. Negm, E.A. Khamis, E.A. Badr, Electrochemical and quantum chemical studies on carbon steel corrosion protection in $1 \mathrm{M} \mathrm{H} 2 \mathrm{SO} 4$ using new eco-friendly Schiff base metal complexes, Journal of the Taiwan Institute of Chemical Engineers 61 (2016) 316-326.

32. M. Yadav, S. Kumar, N. Tiwari, I. Bahadur, E.E. Ebenso, Experimental and quantum chemical studies of synthesized triazine derivatives as an efficient corrosion inhibitor for N80 steel in acidic medium, Journal of Molecular Liquids 212 (2015) 151-167.

33. K.O. Sulaiman, A.T. Onawole, Quantum chemical evaluation of the corrosion inhibition of novel aromatic hydrazide derivatives on mild steel in hydrochloric acid, Computational and Theoretical Chemistry 1093 (2016) 73-80.

34. P. Singh, A. Singh, M.A. Quraishi, Thiopyrimidine derivatives as new and effective corrosion inhibitors for mild steel in hydrochloric acid: Electrochemical and quantum chemical studies, Journal of the Taiwan Institute of Chemical Engineers 60 (2016) 588-601.

35. A. Khadiri, R. Saddik, K. Bekkouche, A. Aouniti, B. Hammouti, N. Benchat, M. Bouachrine, R. Solmaz, Gravimetric, electrochemical and quantum chemical studies of some pyridazine derivatives as corrosion inhibitors for mild steel in $1 \mathrm{M}$ $\mathrm{HCl}$ solution, Journal of the Taiwan Institute of Chemical Engineers 58 (2016) 552-564.

36. S. Kaya, C. Kaya, L. Guo, F. Kandemirli, B. Tüzün, İ. Uğurlu, L.H. Madkour, M. Saraçoğlu, Quantum chemical and molecular dynamics simulation studies on inhibition performances of some thiazole and thiadiazole derivatives against corrosion of iron, Journal of Molecular Liquids 219 (2016) 497-504.

37. T.K. Chaitra, K.N. Mohana, D.M. Gurudatt, H.C. Tandon, Inhibition activity of new thiazole hydrazones towards mild steel corrosion in acid media by thermodynamic, electrochemical and quantum chemical methods, Journal of the Taiwan Institute of Chemical Engineers 67 (2016) 521-531.

38. H.M. Abd El-Lateef, A.M. Abu-Dief, M.A.A. Mohamed, Corrosion inhibition of carbon steel pipelines by some novel Schiff base compounds during acidizing treatment of oil wells studied by electrochemical and quantum chemical methods, Journal of Molecular Structure 1130 (2017) 522-542.

39. A. Bautista, S.M. Alvarez, E.C. Paredes, F. Velasco, S. Guzman, Corrugated stainless steels embedded in carbonated mortars with and without chlorides: 9-Year corrosion results, Construction and Building Materials 95 (2015) 186-196.

40. G. Qiao, B. Guo, J. Ou, F. Xu, Z. Li, Numerical optimization of an impressed current cathodic protection system for reinforced concrete structures, Construction and Building Materials 119 (2016) 260-267.

41. M. Valipour, F. Pargar, M. Shekarchi, S. Khani, M. Moradian, In situ study of chloride ingress in concretes containing natural zeolite, metakaolin and silica fume exposed to various exposure conditions in a harsh marine environment, Construction and Building Materials 46 (2013) 63-70.

42. A. Dousti, R. Rashetnia, B. Ahmadi, M. Shekarchi, Influence of exposure temperature on chloride diffusion in concretes incorporating silica fume or natural zeolite, Construction and Building Materials 49 (2013) 393-399. 


\section{International Journal of Current Science Research and Review}

ISSN: 2581-8341

Volume 04 Issue 02 February 2021

DOI: 10.47191/ijcsrr/V4-i2-04, Impact Factor: 6.825

IJCSRR @ 2021

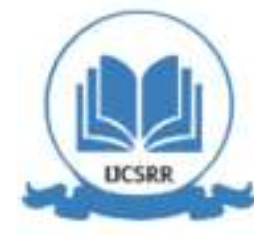

www.ijcsrr.org

43. P. Van den Heede, M. Maes, N. De Belie, Influence of active crack width control on the chloride penetration resistance and global warming potential of slabs made with fly ash+silica fume concrete, Construction and Building Materials 67 (2014) 74-80.

44. N. Chousidis, I. Ioannou, E. Rakanta, C. Koutsodontis, G. Batis, Effect of fly ash chemical composition on the reinforcement corrosion, thermal diffusion and strength of blended cement concretes, Construction and Building Materials 126 (2016) 86-97.

45. G.F. Huseien, M.M. Tahir, J. Mirza, M. Ismail, K.W. Shah, M.A. Asaad, Effects of POFA replaced with FA on durability properties of GBFS included alkali activated mortars, Construction and Building Materials 175 (2018) 174-186.

46. C.A. Loto, O.O. Joseph, R.T. Loto, A.P.I. Popoola, Inhibition effect of vernonia amygdalina extract on the corrosion of mild steel reinforcement in concrete in $3.5 \mathrm{M} \mathrm{NaCl}$ environment, International Journal of Electrochemical Science 8 (2013) $11087-11100$.

47. D.G. Eyu, H. Esah, C. Chukwuekezie, M. Ismail, Effect of green inhibitor on the corrosion behaviour of reinforced carbon steel in concrete, ARPN Journal of Engineering and Applied Sciences 8(5) (2013) 326-332.

48. J.O. Okeniyi, C.A. Loto, A.P.I. Popoola, Electrochemical Performance of Anthocleista djalonensis on Steel-Reinforcement Corrosion in Concrete Immersed in Saline/Marine Simulating-Environment, Transactions of the Indian Institute of Metals 67(6) (2014) 959-969.

49. S.A. Asipita, M. Ismail, M.Z.A. Majid, Z.A. Majid, C. Abdullah, J. Mirza, Green Bambusa Arundinacea leaves extract as a sustainable corrosion inhibitor in steel reinforced concrete, Journal of Cleaner Production 67 (2014) 139-146.

50. J.O. Okeniyi, C.A. Loto, A.P.I. Popoola, Morinda Lucida Effects on Steel-reinforced Concrete in 3.5\% NaCl: Implications for Corrosion-protection of Wind-energy Structures in Saline/Marine Environments, Energy Procedia 50 (2014) $421-428$.

51. M.A. Asaad, M. Ismail, P.B. Raja, N.H.A. Khalid, Rhizophora apiculata as eco-friendly inhibitor against mild steel corrosion in $1 \mathrm{M} \mathrm{HCl}$, Surface Review and Letters 24(8) (2017) 1-11.

52. J.O. Okeniyi, O.A. Omotosho, O.O. Ogunlana, E.T. Okeniyi, T.F. Owoeye, A.S. Ogbiye, E.O. Ogunlana, Investigating prospects of Phyllanthus muellerianus as eco-friendly/sustainable material for reducing concrete steel-reinforcement corrosion in industrial/microbial environment, Energy Procedia 74 (2015) 1274-1281.

53. S.P. Palanisamy, G. Maheswaran, C. Kamal, G. Venkatesh, Prosopis juliflora-A green corrosion inhibitor for reinforced steel in concrete, Research on Chemical Intermediates 42(12) (2016) 7823-7840.

54. W. Ye, Q. Huang, X. Liu, G. Hu, A facile synthesis of CaF2:Eu2+ nanoparticles using citrate-stabilized Au catalysts, Acta Materialia 122 (2017) 420-430.

55. V. Dhand, L. Soumya, S. Bharadwaj, S. Chakra, D. Bhatt, B. Sreedhar, Green synthesis of silver nanoparticles using Coffea arabica seed extract and its antibacterial activity, Materials Science and Engineering: C 58 (2016) 36-43.

56. O.S. Oluwafemi, T. Mochochoko, A.J. Leo, S. Mohan, D.N. Jumbam, S.P. Songca, Microwave irradiation synthesis of silver nanoparticles using cellulose from Eichhornia crassipes plant shoot, Materials Letters 185 (2016) 576-579.

57. H. Joy Prabu, I. Johnson, Plant-mediated biosynthesis and characterization of silver nanoparticles by leaf extracts of Tragia involucrata, Cymbopogon citronella, Solanum verbascifolium and Tylophora ovata, Karbala International Journal of Modern Science 1(4) (2015) 237-246.

58. S. Ahmed, M. Ahmad, B.L. Swami, S. Ikram, A review on plants extract mediated synthesis of silver nanoparticles for antimicrobial applications: A green expertise, Journal of advanced research 7(1) (2016) 17-28.

59. A. Khamhaengpol, S. Siri, Fluorescent light mediated a green synthesis of silver nanoparticles using the protein extract of weaver ant larvae, Journal of photochemistry and photobiology. B, Biology 163 (2016) 337-44.

60. S. Kummara, M.B. Patil, T. Uriah, Synthesis, characterization, biocompatible and anticancer activity of green and chemically synthesized silver nanoparticles - A comparative study, Biomedicine \& pharmacotherapy $=$ Biomedecine \& pharmacotherapie 84 (2016) 10-21.

61. A.Y. Ghidan, T.M. Al-Antary, A.M. Awwad, Green synthesis of copper oxide nanoparticles using Punica granatum peels extract: Effect on green peach Aphid, Environmental Nanotechnology, Monitoring \& Management 6 (2016) 95-98.

62. E.M.S. Azzam, A.A. Abd El-Aal, Corrosion inhibition efficiency of synthesized poly 12-(3-amino phenoxy) dodecane-1thiol surfactant assembled on silver nanoparticles, Egyptian Journal of Petroleum 22(2) (2013) 293-303. 


\section{International Journal of Current Science Research and Review}

ISSN: 2581-8341

Volume 04 Issue 02 February 2021

DOI: 10.47191/ijcsrr/V4-i2-04, Impact Factor: 6.825

IJCSRR@ 2021

www.ijcsrr.org

63. M.M. Solomon, S.A. Umoren, E.J. Abai, Poly(methacrylic acid)/silver nanoparticles composites: In-situ preparation, characterization and anticorrosion property for mild steel in H2SO4 solution, Journal of Molecular Liquids 212 (2015) 340-351.

64. M.M. Solomon, S.A. Umoren, In-situ preparation, characterization and anticorrosion property of polypropylene glycol/silver nanoparticles composite for mild steel corrosion in acid solution, Journal of colloid and interface science 462 (2016) 29-41.

Cite this Article: Mohammad Ali Asaad, Mohammed Noori Hussein, Ahmad Majied Alkadhimi, Ali Taha Saleh (2021). Commercial and Green Corrosion Inhibitors for Reinforced Concrete Structures: A Review. International Journal of Current Science Research and Review, 4(2), 89-99 